\title{
1. The impact of regional cooperation and integration drivers on economic productivity and welfare, with particular attention to Southeast Asia
}

\section{INTRODUCTION}

Geography and related histories shape regional cooperation and integration (RCI), and factor markets (human resource composition and natural resources). In the early 1990s, regional economic integration efforts in Asia and Europe were boosted by geopolitical events in both continents with the disappearance of the Soviet empire. Also in the early 1990s, the Asian Development Bank (ADB) began supporting concrete regional cooperation projects, for instance, in the Greater Mekong Subregion (GMS) and in Central Asia (Central Asian Regional Economic Cooperation (CAREC)). Coincidentally for at least 25 years since about 1990, the field of economic geography has been developing analytic tools which help us better understand how an economic landscape evolves and is shaped (Desmet and Rossi-Hansberg, 2014; Boschma and Martin, 2010; World Bank, 2008; Krugmann, 1991; among many others). These analytic and knowledge tools illuminate how wealth is generated as an outcome of productivity growth. Within this framework, economic actors pursue targets, which can be obtained by using policy instruments aimed at influencing key identified drivers of desirable targets.

This first chapter reviews the drivers, instruments, and tools that link RCI to productivity. Multilateral institutions have identified key drivers of productivity for emerging economies. This study first characterizes types of productivity for the reader (see Figure 1.1, summarizing impact paths from RCI to productivity and competitiveness).

A review of the empirical literature (Brunner and Prasad, 2014) finds only a few key RCI policy instruments, which energize identified regional integration drivers of productivity growth. These instruments fall under 


\begin{tabular}{|c|c|c|c|}
\hline $\begin{array}{c}\text { POLICY } \\
\text { INSTRUMENT }\end{array}$ & TOOL BOX & DRIVER & $\begin{array}{l}\text { WELFARE } \\
\text { IMPACT }\end{array}$ \\
\hline Labor market policy & Mobility & Agglomeration & $\begin{array}{l}\text { Productivity + } \\
\text { Distribution }\end{array}$ \\
\hline $\begin{array}{l}\text { Skill development } \\
\text { policy }\end{array}$ & Capacity & VA Share in GVC & $\begin{array}{l}\text { Competitiveness + } \\
\text { Cohesion }\end{array}$ \\
\hline $\begin{array}{l}\text { FDI, technology } \\
\text { policy }\end{array}$ & Capacity & $\begin{array}{l}\text { VA Share in GVC } \\
\text { Heterogeneity }\end{array}$ & $\begin{array}{l}\text { Productivity + } \\
\text { Cohesion }\end{array}$ \\
\hline $\begin{array}{l}\text { Corridor } \\
\text { development policy }\end{array}$ & Mobility & Agglomeration & $\begin{array}{l}\text { Productivity + } \\
\text { Distribution }\end{array}$ \\
\hline Cluster policy & Analysis & $\begin{array}{l}\text { Human Capital } \\
\text { Intensity }\end{array}$ & Competitiveness \\
\hline Innovation policy & Research & $\begin{array}{l}\text { Structure } \\
\text { Transformation }\end{array}$ & Competitiveness \\
\hline Competition policy & Structure & $\begin{array}{l}\text { Openness with } \\
\text { Scale Economies }\end{array}$ & $\begin{array}{l}\text { Productivity + } \\
\text { Cohesion }\end{array}$ \\
\hline
\end{tabular}

Notes: $\quad \mathrm{FDI}=$ foreign direct investment $; \mathrm{GVC}=$ global value chain $; \mathrm{RCI}=$ regional cooperation and integration; $\mathrm{VA}=$ value-added.

Source: Author.

\section{Figure 1.1 Impact paths: regional cooperation and integration to welfare}

the policy categories of (a) competition, skills and innovation incentives; (b) agglomeration from cluster development; (c) economic corridor development and connectivity; (d) trade facilitation; and (e) foreign direct investment (FDI) and related technology transfer.

The integration and interlinkage of markets through regional integration can add a set of drivers to productivity growth in terms of (a) trade agglomeration economies and the human capital intensity of regional production; (b) regional economies of scale; (c) structural transformation and regional heterogeneity of the production; (d) increases in regional value-added content in trade; and (e) trade opening of the economy. This study focuses primarily on these regional drivers of emerging economies' productivity.

The World Development Report (World Bank, 2008) demonstrates clearly that the way to get the benefits of both agglomeration and scale of production, and the benefits from a convergence of welfare is RCI. This is confirmed by the Baltic Sea Region (BSR) experience, as analyzed in Chapter 2. In addition, an extensive body of literature from recent years demonstrates that regions as shown in the BSR greatly benefit from active government policies, such as fiscal, cohesion, labor market and financial inclusion policies in terms of welfare convergence. 


\section{THE CHALLENGE OF SLOWING PRODUCTIVITY GROWTH}

Since 1965, East Asia has exhibited the world's highest productivity growth, followed by the European Union's first 15 countries (the EU-15), which are mostly wealthy, northern European countries, and then by the rest of Asia, mainly 'developing Asia' (Badunenko et al., 2013). However, those growth figures in East Asia, as well as in the rest of Asia, are down significantly following the 1997 Asian financial crisis, partly for reasons that have inhibited economies' full leverage of RCI drivers and instruments of productivity growth. Presently, there is a gradual and protracted slowdown in economic growth of developing Asia. A key feature of productivities in Asia is the large differential across economies and sectors (see Figures 1.2 to 1.6; ADB, 2014).

This is due, in part, to the inability of Asian developing economies to capture greater value from traded services and production. Generally, productivity and related economic growth are driven by the increasingly

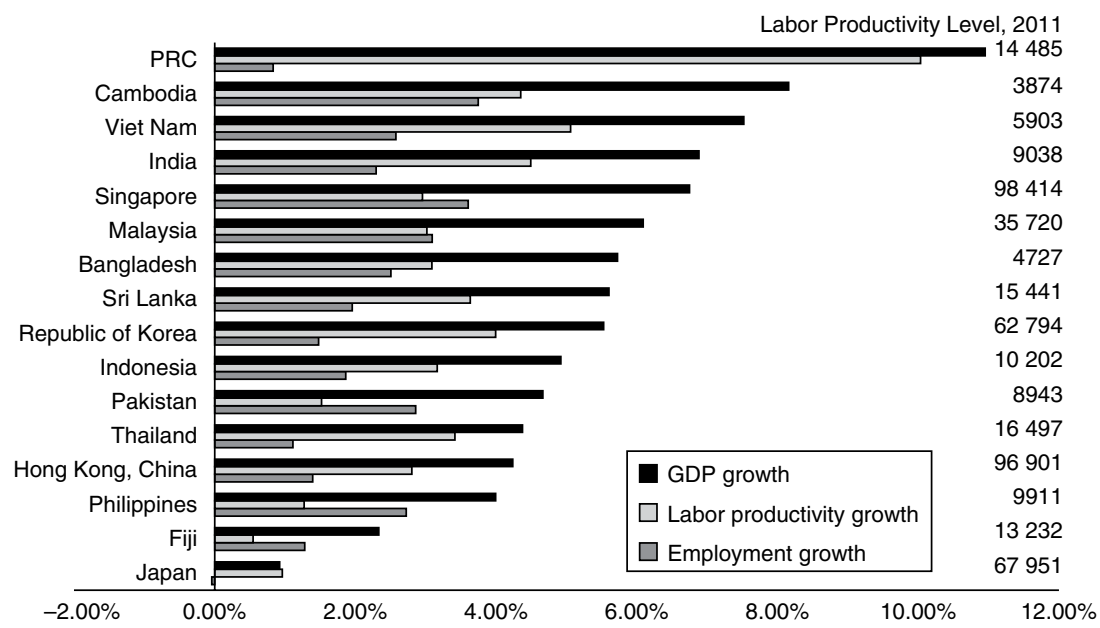

Notes:

GDP $=$ gross domestic product PRC $=$ People's Republic of China.

Period for Cambodia is 1993-2011.

GDP growth is calculated using local currency at constant prices. Labor productivity level is constant in 2005 purchasing power parity, US\$.

Source: Conference Board Total Economy Database, January 2014 edition.

Figure 1.2 Gross domestic product, labor productivity, and employment growth, 1990-2011 


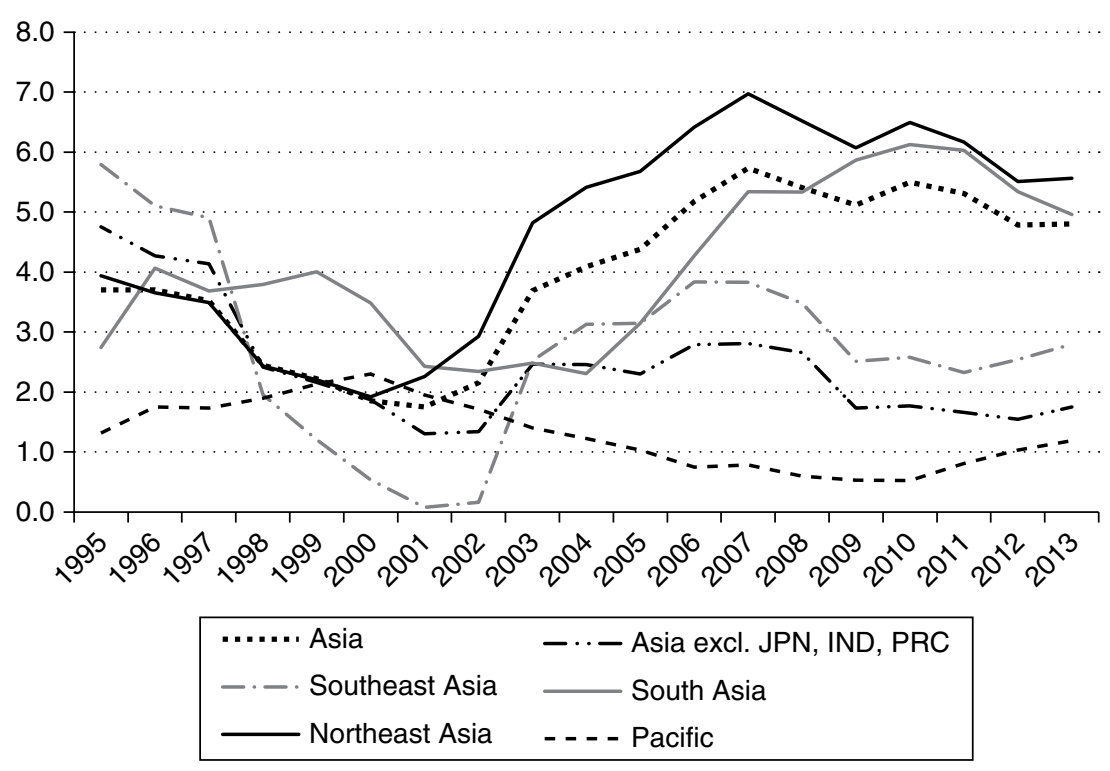

Notes:

PRC = People's Republic of China; IND = India; JPN = Japan.

Years refer to endpoints of 5-year averages computed using compounded annual growth rates.

Source: Conference Board Total Economy Database, January 2014 edition.

\section{Figure 1.3 Labor productivity growth (\%)}

efficient use of factors of production (that is, labor, capital, skilled human resources), and by investment in technology, innovation and knowledge to move a production possibility frontier outward. Furthermore, with increased supply economies of scale, positive spillovers, for instance, from agglomeration of economic activities can further accelerate productivity and growth.

Regional economic structure is essential when it comes to capturing value-added along trade networks. Eastern European economies have done well in integrating with regional and global value chains, and they are increasing their share of value-added, whereas Central Asian economies have largely been unable to integrate (Shepotylo, 2013). This has to do with the accessibility of markets and the economic density of activity in a region. RCI, however, can help reduce disadvantage in geographic structure, in the reduction of the cumulative value of tariff and non-tariff barriers, and with the removal of regulatory weaknesses, and weaknesses in firm 


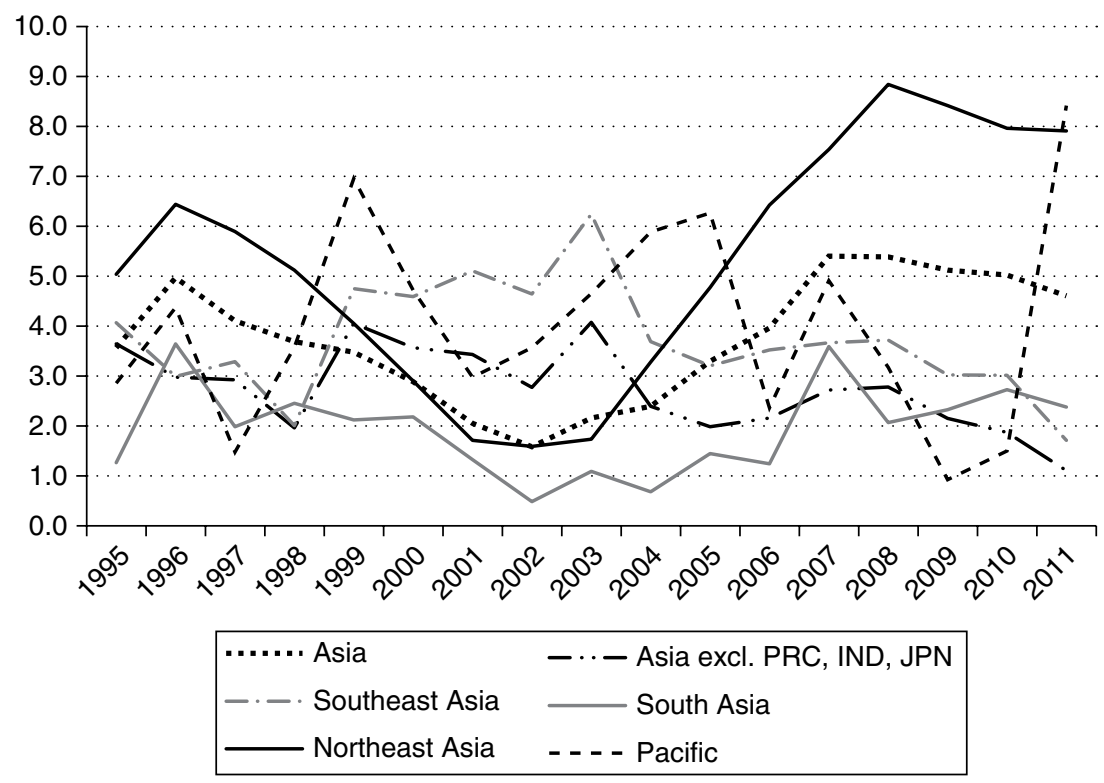

Notes:

PRC = People's Republic of China; IND = India; JPN = Japan.

Years refer to endpoints of 5-year averages computed using compounded annual growth rates.

Source: Asian Productivity Organization database.

Figure 1.4 Agriculture: labor productivity growth (\%)

structure and productivity heterogeneity, among others. Firm innovation, which is a major factor impacting competitiveness and growth, is distinctly conditioned on the geography in which it is embedded.

\section{REGIONAL DRIVERS OF PRODUCTIVITY}

\subsection{Agglomeration of Resources and Spatial Division of Labor}

Regional skilled labor migration can be a driver of productivity growth by spreading the use of technology from cutting edge innovation locations to other, newly emerging innovation clusters. In high-income economies, skill-biased job creation is rooted in research and development (R\&D); in middle-income economies, skill bias is rooted in imitation-based 


\section{BOX 1.1 TYPES OF PRODUCTIVITY: A REVIEW}

\section{Labor Productivity, Output (in Value-added Terms) per Worker and Unit Labor Costs}

One key factor in productivity growth is the change in the productivity of labor. The most desirable measure of labor productivity is the value added by one labor (person) per unit of time (for instance, an hour). Unit labor cost is the wage cost of labor in real terms per unit of value added.

\section{Capital Productivity}

Similarly, capital productivity is measured as the value added by unit of capital, per unit of time.

\section{Total Factor Productivity (TFP)}

Limitations of single-factor productivities are well known, as labor productivity, for instance, is affected by the excluded input factors of capital and technology. Hence, research often uses TFP as an appropriate productivity measure, as TFP is invariant to the intensity of use of all observable factor inputs to produce a unit of value added (labor, capital, technology used as a residual) - variations in output produced from a fixed set of inputs, etc., see Syverson, 2011, p.330. Badunenko et al. (2013), using a large dataset of countries from 1965 to 2007, find that lessdeveloped economies benefit mainly from capital accumulation-driven (labor) productivity, whereas relatively wealthy economies benefit much more from technology-driven productivity when world (labor) productivity (TFP) growth is decomposed into its components. Roland-Holst and Sugiyarto (2014) attribute TFP growth in Asia mainly to capital deepening. In practice, there are also measurement concerns with TFP. It is harder to measure than single factor productivities, as, for instance, it is difficult to measure capital stock. Recently in the literature, efforts have been made to adjust for quality measurement of real output (Benkovskis and Woerz, 2013). This has to be done on a detailed sector or even product level, and based on firm-level statistics. Firm-level statistics are used to analyze key factors that drive TFP, for instance, the business environment in which firms operate (as measured by an infrastructure indicator, financial development indicator, governance indicator, labor market flexibility indicator, labor quality indicator, and a competition indicator) has significant influence on their productivity (Anos-Casero and Udomsaph, 2009).

\section{Productivity versus Competitiveness}

Competitiveness is not the same as productivity (for example, TFP). Modern definitions of competitiveness attempt to measure how productively the resources in a region are employed for trade. Competitiveness is a comprehensive framework, which attempts to capture all factors that drive the 'prosperity potential' (Ketels, 2013 , p. 270) of a location, and with focus on factors amenable to policy action. 


\begin{abstract}
Value-added goods produced domestically and exported (vs. imported) are the key here to determine, for instance, the competitiveness of a country or of a region (Melitz and Redding, 2014). The drivers of competitiveness include the quality of institutions (such as the legal system), the quantity of government investments in infrastructure, the degree of competition, the quality of the workforce, the nature of macroeconomic policies (for example, the size of the public debt), the TFP, and so on. Timmer et al. $(2013$, p. 6$)$ define the competitiveness of a country as 'the ability to perform activities that meet the test of international competition and generate increasing income and employment'. Based on world input-output tables, they then measure competitiveness based on value-added and jobs involved in global value chains. With appropriate indicators of competitiveness in place, an impact assessment system could focus on the effects of $\mathrm{RCl}$ efforts on competitiveness.

A new measure of aggregate competitiveness of a location is gross national income (or the closest possible measure that can be achieved locally, which might be gross value added) divided by population of employable age (Enright, 2013). This is a simple measure of how productively the most important resource - human capital - is employed for trade. The aggregate measure is indicative of a set of underlying fundamental causes that policy instruments address to achieve, for instance, higher growth. Delgado et al. (2012) organize these factors or drivers into three groups: (a) social infrastructure and political institutions; (b) monetary and fiscal policy; and (c) microeconomic competitiveness. It is important to note that none of the causal factors individually offer a set path to productivity and inclusive growth. New research on competitiveness aims to capture a breadth of factors that enable each region to harness those drivers that matter most given its particular circumstance at a given point in time (Ketels, 2013).
\end{abstract}

specialization, which can emanate from FDI and from trade and market integration (for example, global value chain) linkages. Policy tools can support this labor migration, as can be seen in the case of the software sector, and in the innovation cluster establishment in the Baltic countries. As skilled workers are scarce in the emerging market economies, the regionally enhanced transmission of ideas and adapted technologies makes this scarce labor resource more productive, and also enhances productivity in cutting edge innovation locations by allowing 'farming-out' and 'imitative innovation'. Regional integration of more productive economies with less productive ones increases the productive heterogeneity among regional firms, according to Melitz and Redding (2014) (see also Brunner and Prasad, 2015), and, as a result, drives up productivity growth.

To the extent that trade expands markets, we would expect to see a greater division of labor as increased specialization takes place. Concurrently, a number of activities previously taking place at the same location might become spatially separated (possibly in different countries or regions). Once spatial division of labor occurs, advantages from labor pooling (lower search costs for workers) and knowledge spillovers (knowledge-sharing 


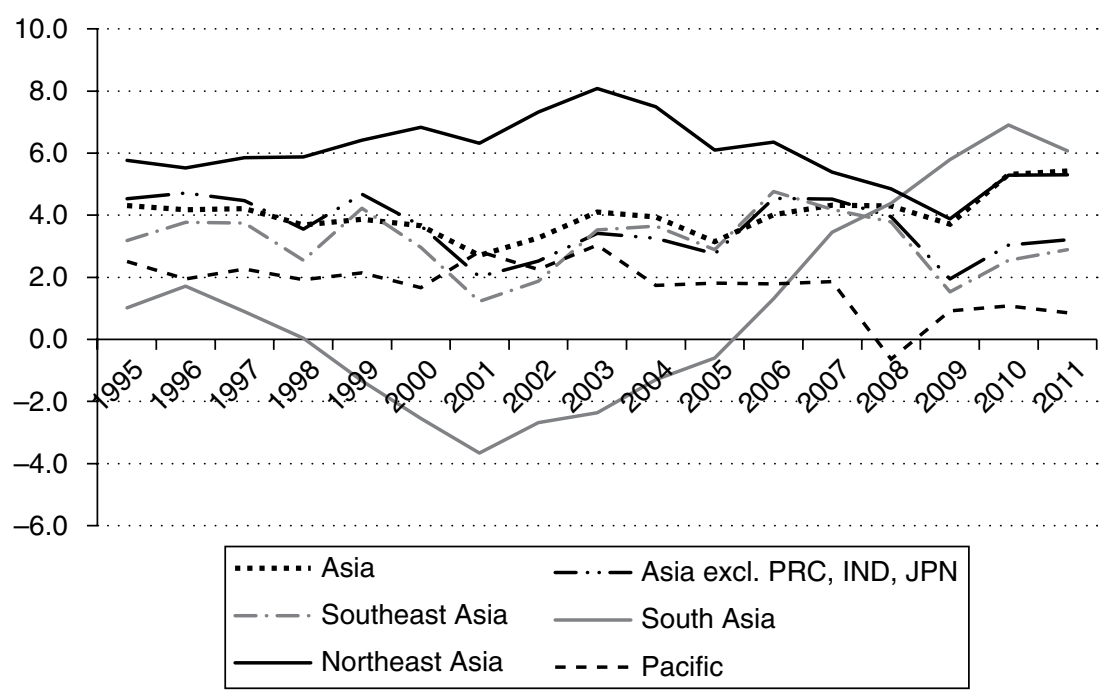

Notes:

PRC $=$ People's Republic of China; IND = India; JPN = Japan.

Years refer to endpoints of 5-year averages computed using compounded annual growth rates.

Source: Asian Productivity Organization database.

Figure 1.5 Manufacturing: labor productivity growth (\%)

among workers) might take place as well. This can create further positive feedback as greater incentives for spatial division of labor arise, creating even greater spillovers. Chaney and Ossa (2012) put forward a recent model linking market size to an endogenous division of labor. It is worth noting that while increased market size does not necessarily imply spatial separation of production, it makes it more likely. This is because the gains from splitting production across locations, to take advantage of location advantages, become greater.

\subsection{Increasing Returns to Scale and Positive Feedback in Exports}

According to Syverson (2011), productivity of firms and the inherent heterogeneity is driven by (a) firm-internal factors (for instance, management, labor quality, R\&D); and (b) by firm-external factors, which are of prime interest here (for instance, agglomeration and spillover effects, competition and sector effects, and the business environment). It is to be 


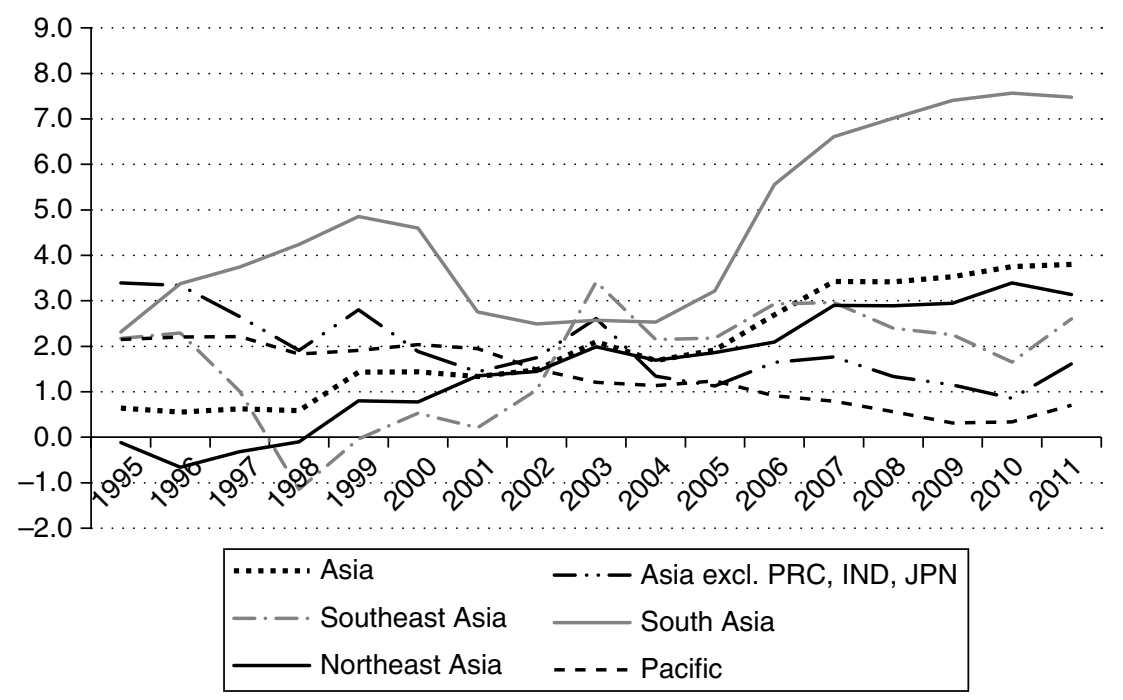

Notes:

PRC $=$ People's Republic of China; IND = India; JPN = Japan.

Years refer to endpoints of 5-year averages computed using compounded annual growth rates.

Source: Asian Productivity Organization database.

Figure 1.6 Services: labor productivity growth (\%)

noted that causality does not run unidirectionally, but there are non-linear feedback mechanisms at play. Exporters tend to agglomerate in locations that provide a more conducive business environment, allow for positive (knowledge, information, innovation and so on) spillover effects and thus make exporters even more productive. Active exporters introduce more new products into new markets and, as a result, diversify their export activity (see Hausmann and Hidalgo, 2010). These positive externality and feedback effects, scale economies and so on allow for efforts to accelerate growth, through applied policy tools financed by public sector interaction with the private sector. According to Ciuriak (2010, p. 19), the heterogeneous firm view of trade puts the policy spotlight on the nexus of tradeRCI-investment-innovation-productivity-growth using such instruments as value chains and market access creation, and the clustering of investment (including FDI) in knowledge and technology-dependent sectors and on innovation-driven firm exports, for example, by small- and mediumsized enterprises (SMEs). 


\subsection{Regional Cooperation and Integration-driven Structural Transformation}

Within sector heterogeneity, structural transformation can further enhance mobility, returns to scale and agglomeration-driven productivity growth. In this way, resources (human and capital) are moved from low value added and low productivity sectors to higher value added and higher productivity sectors. This can be driven by competition and trade in open regionalism. Figure 1.7 shows a mixed picture of structural transformation. For instance, in Bangladesh and Malaysia, structural change from

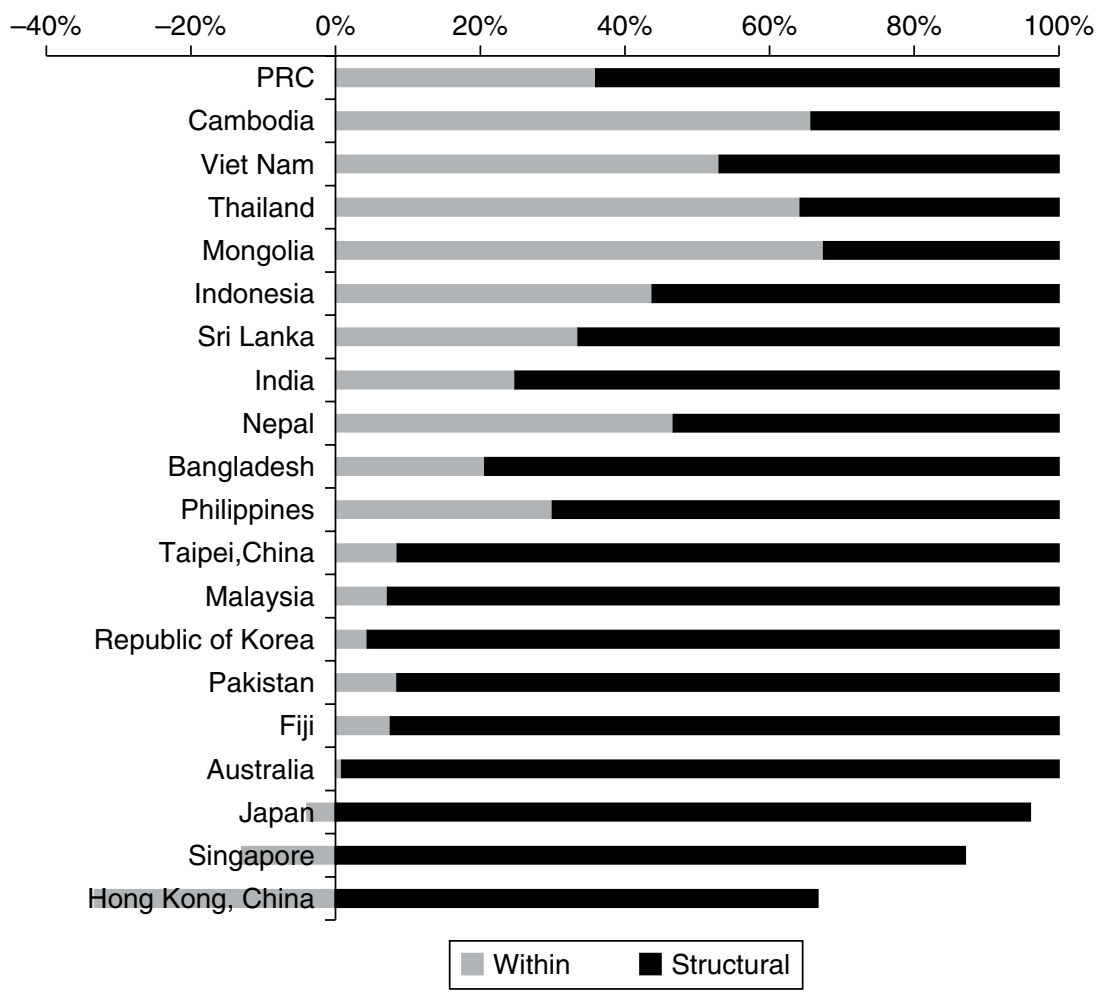

Notes:

PRC $=$ People's Republic of China.

Period for Cambodia is 1993-2011.

Source: Computed from Asian Productivity Organization database.

Figure 1.7 Structural and non-structural labor productivity growth, 1990-2011 (\%) 
low labor productivity to higher productivity sectors was significant for productivity growth; in Cambodia, the Philippines, and Thailand, it was not (Figure 1.7).

\subsection{Moving into and up Global Value Chains (Increasing Value-added Share)}

Value chains, reflecting value-added trade and thus structural transformation, are a way of describing the full range of activities that firms and workers distributed over a wide geography perform to bring a product or service from its conception to the end-user (Cattaneo et al., 2013). Geography becomes an important variable in this concept as production takes place at different scales (local, national, regional and global), and is driven by relative differences between the local, national and regional scales. Costinot et al. (2013) offer a comprehensive theoretical exploration of how changes in technology and productivity - driven by local, regional to global value chains (GVCs) - affect participating countries. First, an increase in the complexity of value chains (which relates to the overall complexity of the final export good) leads all countries to move up the value chain; however, at different rates, with the countries at the upper end (close to markets) moving up relatively more, therefore inequality between countries and regions along global value chains increases (Costinot et al., 2013, p. 117). Second, as production processes along value chains become more standardized as goods mature (that is, as technology diffuses down the value chain), all countries move up the value chain; however, countries and regions at the lower end benefit relatively more. Therefore, inequality between countries and regions decreases (Costinot et al., 2013, p. 119).

Overall, GVCs increase the average skill intensity worldwide, and so skill-premiums rise. To elucidate value-added structural adjustments, the dynamic Asian Regional CGE (ARC) Global Trade Analysis Project model described in more detail in Appendix 1 traces sector shifts in bilateral trade flows in intermediate and final goods. Figure 1.8 illustrates our starting point, graphing global composition of trade in goods and services, bilaterally, as a percentage of the total, by origin (vertical axis), and destination (bars).

In Figure 1.9, by contrast, we provide global share data on value added in traded goods and services (estimated from domestic value-added shares in originating countries). The distinction between these two, goods movement versus national income embodied in trade, is an important one, and has supported a large policy research literature. Clearly, if the intent of trade is to achieve income growth, the value-added perspective is the more 


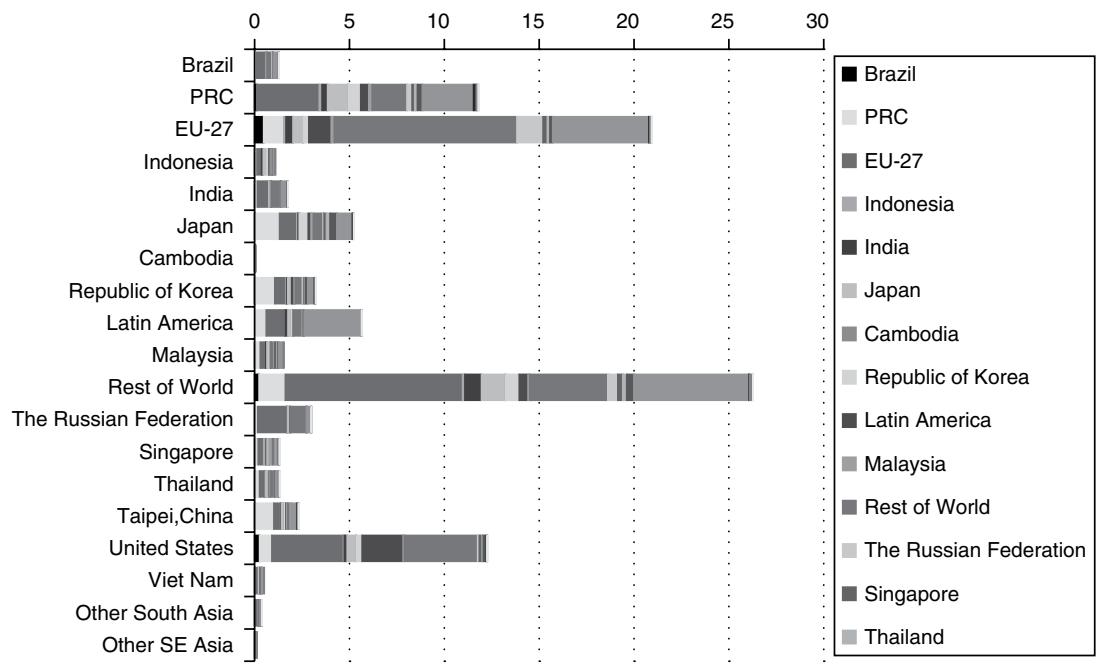

Notes: $\quad$ PRC $=$ People's Republic of China $;$ EU-27 $=$ the first 27 countries in the European Union; $\mathrm{SE}=$ Southeast.

Source: Global Trade Analysis Project (GTAP), www.gtap.org.

Figure 1.8 Bilateral trade flows, 2010 by origin (left axis) and destination (right key) (\% of total)

appropriate. Comparing Figures 1.8 and 1.9 also makes clear that the two perspectives differ in important ways.

There are some key assumptions in this theoretical and empirical exploration, one of them being that intermediate goods along the value chain are freely traded; that is, they benefit from complete trade facilitation. Hence trade facilitation is another key RCI policy instrument that can (positively) influence regional inclusiveness and cohesion, as discussed below.

\subsection{Trade Opening of Economy}

Open regionalism (through $\mathrm{RCI}$ ) helps improve productivity through an open trade environment. Open economies have higher productivity as firms are exposed to competition. This allows more efficient firms to thrive, with the inefficient ones disappearing in the process or losing market shares. Trade allows producers to choose from a variety of inputs, both local and foreign, making it possible to reduce costs and to improve technology of production. Boler et al. (2012) show how a greater variety 


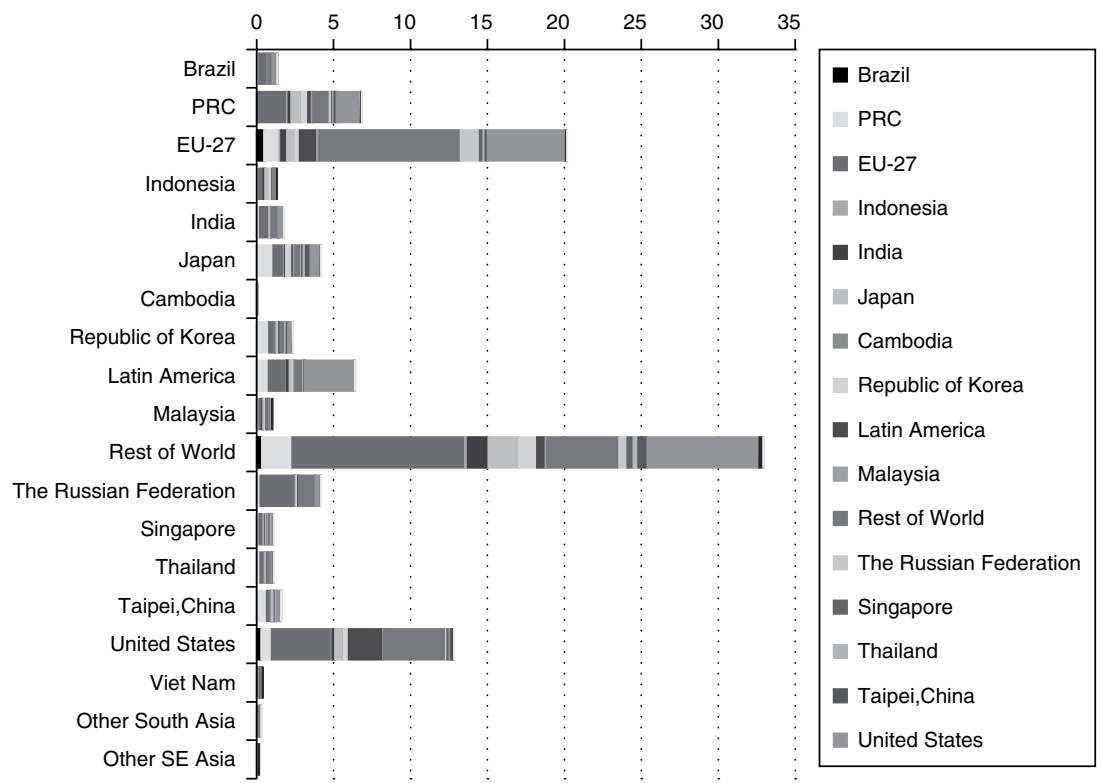

Notes: $\quad$ PRC $=$ People's Republic of China $;$ EU-27 $=$ the first 27 countries in the European Union; $\mathrm{SE}=$ Southeast.

Source: Global Trade Analysis Project (GTAP), www.gtap.org.

Figure 1.9 Bilateral value-added flows, 2010 by origin (left axis) and destination (right key) (\% of total)

of inputs and access to GVCs through trade opening complements innovation, and hence productivity growth.

\section{FACTORS AND INSTRUMENTS}

\subsection{Policies Affecting Firm Structure (Competition, Skills, Innovation Incentives)}

A diversified, heterogeneous-in-productivity firm structure obviates, as recent literature seems to indicate, the need to specifically support SMEs (for instance, Haltiwanger et al., 2013). What the recent literature is increasingly supporting is strong evidence that it is innovative firms, including small innovative ones, that create the jobs (Vivarelli, 2014). Smart innovation and specialization have become a recent focus of policy attention 
in Organisation for Economic Co-operation and Development (OECD) countries. Smart innovations and specialization are skill-based, going back to Griliches' seminal paper (1969). The new jobs created, which sustain income growth, are the skilled ones, and they are added in fast-growing new enterprises, small or not so small. This applies to economies at different income levels, as will be discussed. As described above, in high-income economies, the skill-biased job creation is rooted in $\mathrm{R} \& \mathrm{D}$ policies. In lower middle-income economies, skill-bias is rooted in imitation-based specialization, which can emanate from FDI (see section 3.5, below, on FDI and technology transfer), and from market integration (GVC) linkages.

The persistence of TFP growth in middle-income countries is dependent on existing external knowledge for innovation, as well as the continuing competitive pressure in firm-specific product markets. For markets to function effectively and competitively, a solid regulatory frame is necessary. Regulation and competition policies and institutions can also be instrumental at a regional level. Broadly, the literature finds a positive and significant relationship between effective, independent competition policy and TFP growth. Trade integration, which leads to increased market size of a region further increases competitive pressure, and this helps enhance regional productivity growth (Melitz and Ottaviano, 2008). The higher productivity effect is driven by more productive firms in a larger regional market.

\subsection{Agglomeration Policies (Special Economic Zones, Clusters)}

The development of GVCs creates patterns of regional development in the network connection between production agglomerations, zones and clusters (Henning and Saggau, 2012), more precisely concentrations of co-located economic activities in related fields. Despite powerful globalization dynamics, a large part of global production is performed in regional clusters. ${ }^{1}$ What causes clusters and makes them work, the prerequisites, triggers, drivers and development processes are divided by Brenner and Muehlig (2013, p.484) into: (a) aspects connected to labor skills; (b) research and imitation and/or innovation; (c) firm interactions and links and sector conditions; and (d) other local conditions. Greater regional integration strengthens tendencies to agglomerate economic activity in regional clusters, unless counteracted otherwise.

\subsection{Economic Corridor Development and Connectivity}

With the importance of networks between firms in clusters, agglomerations and along value chains, the increase in efficiency of the physical and 
information links becomes a conjoint, crucial driver that determines productivity and inclusive growth effects. RCI agreements include a variety of steps to reduce the costs and complexity of engaging in cross-border trade. This can include the facilitation of border crossings, as well as harmonization of regulations so that exporting and importing are simple, transparent and predictable.

\subsection{Trade Facilitation}

There is no universal definition of trade facilitation. It is useful to think of trade facilitation as reducing transaction costs other than tariffs and quotas. Trade facilitation includes both 'hard' and 'soft' dimensions. Hard dimensions include infrastructure investments in transportation, border crossings, ports and so on. Soft dimensions include easing regulatory burdens on trade, simplifying customs procedures and so on. Estimation of trade costs and their effects are discussed in Anderson and Van Wincoop (2004) and Portugal-Perez and Wilson (2012), and in a comprehensive way by Sourdin and Pomfret (2012). From their extensive survey, Anderson and Van Wincoop (2004) make a number of important points. First, that trade costs (all transport, border-related and local distribution costs) are large in global perspective. Second, infrastructure investments, law enforcement and property rights enforcement are more important than tariffs and other direct policy instruments. Third, trade costs have large welfare implications. And fourth, details of trade costs matter for economic geography. All of these imply that trade facilitation measures, when effective, will have very substantial effects. Portugal-Perez and Wilson (2012) develop indicators of 'hard' and 'soft' trade facilitation and estimate their effects on export performance in developing countries. They find that trade facilitation reforms have a positive effect, particularly so for physical infrastructure investments and regulatory reform to improve the business environment.

\subsection{Foreign Direct Investment; Technology Transfer}

Support for FDI is an important policy instrument to enhance the technology factor in production.

There is a longstanding and vast body of literature on the role of FDI in technology change and productivity growth. FDI is associated with increases in TFP, accompanied by output increase, and increased import and export intensity. The literature relating FDI's role in development with regional integration is much narrower. This literature emphasizes the role of RCI and FDI in enhancing market access through regional and global value chain development. 


\section{REGIONAL COOPERATION AND INTEGRATION AND PRODUCTIVITY GROWTH AFFECTING WELFARE DISTRIBUTION}

The Kuznets curve suggests that in the early stages of economic development, inequality increases and this increase reflects structural changes that drive growth and productivity. In the late stages of economic development, inequality decreases. Thus, most developed economies are classified as high income and low inequality countries. However, when welfare distribution is particularly unequal, structural change and resulting growth is impeded. Castells-Quintana and Royuela (2014) reference literature which indicates a Gini coefficient of 0.37 as maximizing growth effects from (a) trade agglomeration economies, and the human capital intensity of regional production; (b) regional economies of scale; (c) structural transformation and regional heterogeneity of production; (d) increases in regional value-added content in trade; and (e) trade opening of the economy.

A range of policies can counteract tendencies toward more unequal regional welfare distribution when RCI favors more productive centers. Technology differentials and the skill-based nature of regionally enhanced productivity growth are important factors in boosting welfare concentration effects from trade integration. While trade and regional integration drive upward to productivity heterogeneity among firms, inducing higher benefits from regional integration, models also show that the greater dispersion of firms leads to greater wage differential (Faggio et al., 2010).

This point was made at length in the World Development Report (World Bank, 2008):

Economic growth will be unbalanced, but development still can be inclusive . . . As economies grow from low to high income, production becomes more concentrated spatially. Some places - cities, coastal areas, and connected countries are favored by producers. As countries develop, the most successful ones also institute policies that make living standards of people more uniform across space. The way to get both the immediate benefits of the concentration of production and the long-term benefits of a convergence in living standards is regional economic integration.

Extensive literature of recent years demonstrates that regions can benefit from active government policies such as innovation policies, cluster policies, labor market policies, social protection and cohesion, and financial inclusion. In the European Union (EU), greater regional welfare dispersion has been counteracted with fiscal support and cohesion policies, as well as increased mobility in the regional labor market. As we see, the Baltic Sea Region effort in this respect has been quite successful. We 
summarize the basket of inclusionary and cohesive policies and measures in four categories: fiscal, cohesion, labor market and financial market.

\subsection{Response Policies}

\section{Fiscal (Asian Development Outlook, 2014)}

Fiscal policies that foster equality of opportunity coordinated on a regional level can tackle rising regional inequalities propelled by RCIdriven productivity growth. The EU has centrally driven and funded cohesion policies aimed at bringing economically lagging regions and areas closer to the average EU welfare levels. As the example of the Baltic Sea Region (BSR) will show, cohesion policies undertaken on national levels can be influenced by regional consensual coordination mechanisms.

\section{Cohesion}

EU cohesion policies allow lagging countries and regions to catch up with the European core economy. A very important part of the cohesion policies is the smart specialization regional policy framework for innovationdriven growth. This can be implemented as in the BSR 'macro-region' through an innovation steering group. The EU provides independence to such 'macro-regions' in their regional cooperation on programs such as regional innovation and skill-based cluster development and investment. Such regional grouping can, for instance, enhance coherence and collaboration of $\mathrm{R} \& \mathrm{D}$ and innovation activities in a region. Horizontal policy coordination can work by setting common goals in terms of regional technology platforms, innovation cluster networks, diagnostic and indicator based tools and infrastructure, and so on (see OECD, 2013, for details). It can develop free movement of researchers, knowledge and technology across a region.

\section{Labor market (European Union: Association of Southeast Asian Nations study)}

As has been shown, increasing firm heterogeneity in terms of productivity, which can be induced by regional integration, can lead to increased wage dispersion, where the most trained and skill-intensive part of the labor force benefits from welfare increase disproportionally to the rest of the labor force. For instance, Faggio et al. (2010) showed that most of the increase in individual wage inequality in the United Kingdom was accounted for by increased productivity dispersion between firms and between sectors. On a regionally coordinated basis, it is important to modernize national labor markets by facilitating labor mobility and the development of skills to increase the participation of labor in the 
formal economy and the better matching of regional labor supply and demand.

\section{Financial inclusion: small- and medium-sized enterprise finance}

Limited access to credit by SMEs limits their ability to purchase imports and technology and their ability to participate in higher value-added GVCs. Improved access to finance by SMEs can offer these firms a productivity boost, enabling them to help absorb increasingly skilled human resources. When SMEs co-locate with larger, especially foreign-owned technology companies, finance helps them integrate into regional and global innovation and production networks. Thus with the absorption of more skilled labor, employment-based welfare can spread through a more integrated region via an ecology of clusters. Key financial market-driven policies designed to enhance SME productivity can support trade and supply-chain finance. More unconventional, second generation regional integration finance tools can also be instituted. For instance, value chain finance can extend reverse factoring through multiple stages of a regional or global value chain, helping SMEs further down the chain to access finance (see ADB, 2014). However, SME finance misdirected to make productivity growth more inclusive across sectors can have an unintended effect of aiding a structural shift from capital intensive high-laborproductivity (manufacturing) sectors to low-labor-productivity (services) sectors, in which SMEs proliferate due to low barriers to entry. Hence it is important to have proper incentives in place that direct finance to innovative SMEs that are deemed to create productive jobs. This is a matter of small firm innovation and specialization policy as well.

\section{NOTE}

1. Clusters are modes of organization of the productive system, characterized by a geographical concentration of a critical mass of economic actors and other organizations, specialized in a common field of activity, developing inter-relations of a market or nonmarket nature, and contributing to innovation and competitiveness of its members and the territory. Clusters often include networks (OECD, 2011, p. 190). 